\title{
The Impact of Giving Caffeine in Coffe (Coffea sp.) Againts the Level of Hemoglobin (Hb) Mus musculus BABLC
}

\author{
Armaita $^{1 *}$, Didin Tohidin ${ }^{2}$, and Afrihatin. $\mathrm{Y}^{3}$ \\ ${ }^{1,2,3}$ Faculty of Sports Sciences, Universitas Negeri Padang Padang, Indonesia \\ *Corresponding author. Email: armaita10mei@gmail.com
}

\begin{abstract}
The tannins and phitat in tea and coffee as well as calcium and phosphorus in milk can bind iron so that it is difficult to absorb (Said, 2004). Caffeine intake from coffee also turns out to make various nutrients bound and damaged. In addition, the content of hemoglobin in the blood will also tend to become unstable and in the end the body will experience a deficiency of red blood cells. This means, the problem of anemia will become more severe. In addition, this coffee consumption will also make the body's immune system decrease significantly so that various health problems can arise (Anonimous, 2015). This type of research is an experiment with a post test only control group design research design that is a design used to measure the effect of treatment in the experimental group by comparing treatment results with the control group ending the treatment period. The study was conducted at the Anatomy Stikes Cup of Sakti Pariaman Cup. Extraction is carried out in the L2DIKTI Laboratory. This research was conducted from March-November 2019. The total number of mice during the study were 32 individuals. The results of this study were tabulated and analyzed data using the $\mathrm{T}$ test of $95 \%$ confidence level. From the results of the sample T-test, the research found that there was a significant relationship between coffee caffeine (Coffea $\mathrm{Sp}$ ) on the level of experimental animal hemoglobin with $\mathrm{p}$ value 0.00 .
\end{abstract}

Keywords: Caffeine, coffee, hemoglobin

\section{INTRODUCTION}

The problems faced by the elderly in general are degenerative diseases, but diseases related to nutritional problems will also increase (Dep. Kes, 2003) [1]. The five main diseases that are mostly suffered by the elderly population in Indonesia are: cancer (2.2\%), tuberculosis (11.5\%), respiratory infections (12.2\%), heart disease - blood vessels $(29.5 \%)$, and anemia $(50 \%)$ (Dep. Kes, 2008) [2]. Based on these data it can be seen that anemia is the most common illness in the elderly in Indonesia.

Foods in Indonesia contain many inhibitors such as phytate and polyphenols. Sources of inhibitors include rice, soy protein, peanuts, beans, tea, coffee and spinach. The habit that is often done by the people of Indonesia in general is to consume tea and coffee every morning and after eating. Tea and coffee have many health benefits, but in fact tea is also known to inhibit the absorption of iron sourced from non-hem (non-heme iron). Hurrell RF., Et all (1999) reported that black tea and concentrated coffee can inhibit the absorption of nonhame iron[3].

The direct causes of anemia include deficiency of nutritional intake from food (iron, folic acid, protein, vitamin $\mathrm{C}$, riboflavin, vitamin $\mathrm{A}$, zinc and vitamin $\mathrm{B} 12$ ), consumption of iron absorption inhibitors such as tea and coffee, infectious diseases, malabsorption, bleeding and increased need (Ramakrishnan, 2001) [4]. Anemia is an early symptom of iron deficiency. There are several nutrients in food that can increase the availability / effectiveness / absorption of Fe, namely vitamin C, some amino acids, and food protein in general (Linder, 2006) [5].

\section{METHODS}

\section{Preparation of animal experiments}

Choose 28 test animals, age 2-3 months, 18-40 g healthy body weight. Prepare a mouse cage complete with a feed and drinking water container. Pad cages of rice powder are replaced every three days. Test animals that will be used are acclimatized in the cage for 1 week. 28 mice were divided into four groups. The first group is the group without treatment (control), the second group is the group that is given coffee at a dose of $0.14 \mathrm{~g} / \mathrm{ml}$, the third group with $0.28 \mathrm{~g} / \mathrm{ml}$, and the last group at a dose of $0.56 \mathrm{~g} / \mathrm{ml}$. 


\section{Preparation of extract caffeine}

Coffee is roasted with a temperature of 1490-2130C. The roasting is stopped when the coffee is easy to solve. This indicates that the ready milled roasted coffee to get coffee powder. Coffee powder is put into a measuring cup, then brewed with ethanol water then macerated (soaking) for 24 hours, then filtrated (filtering) separates the water with its pulp, then evaporation (heated) to produce extracts from the coffee. the volume of coffee solution used is as follows: conversion of experimental animals $\times$ coffee solution calculation : $0.14 \mathrm{~g} \times 200 \mathrm{ml}=$ $0.28 \mathrm{~g} / \mathrm{ml}$. So $28 \mathrm{~g} / \mathrm{ml}$ is the second dose for the first dose $1 / 2$ of dose 2. For dose 3, 2 times the second dose. Dosage 1: $1 / 2$ of $28 \mathrm{~g} \mathrm{/} \mathrm{ml}=0.14 \mathrm{~g} / \mathrm{ml}$; Dose 2: $0.14 \mathrm{~g} \times$ $200 \mathrm{ml}=0.28 \mathrm{~g} / \mathrm{ml}$; Dose $3: 2 \times 28 \mathrm{~g} / \mathrm{ml}=0.56 \mathrm{~g} / \mathrm{ml}$ Coffee powder is given by brewing with ethanol water and then given to mice through a sonde.

\section{RESULT AND DISCUSSION}

\section{A. Results}

Table 1. Test for normality of the impact of caffeine in coffee drinks on hemoglobin $(\mathrm{Hb})$ levels of mus musculus BABLC $(n=24)$.

\begin{tabular}{|l|r|r|r|}
\hline \multirow{2}{*}{} & \multicolumn{3}{|c|}{ Shapiro-Wilk } \\
\cline { 2 - 4 } & Statistic & \multicolumn{1}{c|}{ df } & \multicolumn{1}{c|}{ Sig. } \\
\hline Hemoglobin & .950 & 28 & \\
\hline
\end{tabular}

Table 2. Analysis of blood hemoglobin results in rats given caffeine coffee drinks (Coffea sp.) $(\mathrm{N}=24)$.

\begin{tabular}{|c|c|c|c|}
\hline \multirow{2}{*}{ Hemoglobin } & $\mathrm{t}$ & $\mathrm{df}$ & Sig. (2-tailed) \\
\cline { 2 - 4 } & 13.612 & 28 & .000 \\
\hline
\end{tabular}

\section{B. Discussion}

The pattern of consumption of major constituent inhibitors in the formation of hemoglobin such as $\mathrm{Fe}$ and protein is a major factor in decreasing hemioglobin levels. It is well known that coffee is a drink that is rich in caffeine and phytate which is a natural inhibitor that can inhibit the absorption of protein and fe. This is consistent with the results obtained, from the results of statistical tests using the Sample T-test it is known that there is a significant effect of coffee administration on hemoglobin levels.

Caffeine is the main substance contained in coffee which is a drink favored by people around the world. Caffeine content in some types of coffee is $95-165 \mathrm{mg}$ at $237 \mathrm{~mL}$ of coffee served by brewing, $47-64 \mathrm{mg}$ at 30 $\mathrm{mL}$ espresso coffee, $63 \mathrm{mg}$ at $237 \mathrm{~mL}$ instant coffee, and $2-5 \mathrm{mg}$ at $237 \mathrm{~mL}$ decaffeinated coffee. The effect of caffeine on blood sugar levels is still unclear (Urzua et al, 2012).

Drinking tea, coffee, and milk after eating actually makes the body lose $\mathrm{Fe}$ which leads to anemia. The tannin and phitat in tea and coffee as well as calcium and phosphorus in milk can bind iron so it is difficult to absorb. For this reason, it is important to give a gap of at least two hours after eating if you want to drink tea, coffee, or milk. Most anemia is caused by iron deficiency as much as $60-70$ percent. It can also be caused by a lack of protein, folic acid, and vitamin B12, vitamin A.

By consuming coffee, anemic sufferers have the potential to experience interference in absorbing iron from food. If this happens, then instead of the body becoming fresher and more alert, what happens is that anemia will become worse. In addition, if anemic sufferers are pregnant women, then pregnant women will also be at risk of significantly decreasing iron levels in the body so that it can harm the fetus. In fact, for the sake of the health and development of the fetus, pregnant women should get far more iron than usual. The presence of caffeine content will apparently make iron unable to circulate smoothly in the blood so that the fetus will have difficulty absorbing it and its development will be disrupted (Soraya et al, 2014) [6].

Caffeine intake from coffee also turns out to make various nutrients bound and damaged. In addition, the content of hemoglobin in the blood will also tend to become unstable and in the end the body will experience a deficiency of red blood cells. This means, the problem of anemia will become more severe. In addition, this coffee consumption will also make the body's immune system decrease significantly so that various health problems can arise (Marina et al, 2015)[7].

\section{CONCLUSION}

The pattern of consumption is a major factor in decreasing hemoglobin levels. Caffeine is the main substance contained in coffee which is a drink favored by people around the world. By consuming coffee, anemic sufferers have the potential to experience interference in absorbing iron from food. The results of this study were tabulated and analyzed data using the $\mathrm{T}$ test of $95 \%$ confidence level. From the results of the sample T-test, the research found that there was a significant relationship between coffee caffeine (Coffea $\mathrm{Sp})$ on the level of experimental animal hemoglobin with $\mathrm{p}$ value 0.00 .

\section{REFERENCES}

[1] Depkes RI. 2003. Program Penanggulangan Anemia Gizi Pada Wanita Usia Subur (WUS). Ditjen Gizi. Jakarta. 
[2] Depkes RI. 2008. Pedoman Penanggulangan Anemia Gizi untuk Remaja Putri dan Wanita Usia Subur. Ditjen Pembinaan Kesehatan Masyarakat. Jakarta.

[3] Hurrel R F., Reddy M., Cook JD.1999. Inhibibition of Nonhem Iron Absorpton in Man by Polypenolic Containing Bevergas. British Journal of Nutrition. (81):289-295

[4] Ramakrishnan,U. 2001. Nutritional Anemias. CRC Press, Boca London, New York Washingon,DC.

[5] Linder, MC. 2006. Biokimia Nutrisi dan Metabolisme. Universitas Indonesia Press. Jakarta.

[6] Anisya Dian Soraya, Supriyono Asfawi, Eko Hartini. 2014. Hubungan antara Kadar Hemoglobin (Hb) dengan Tingkat Kelelahan Kerja pada Polisi Lalu Lintas Wilayah Semarang Barat 2014

[7] Marina, Rahayu Indriasari, Nurhaedar Jafar. 2014. Konsumsi Tanin dan Fitat sebagai Determinan Penyebab Anemia pada Remaja Putri di Sma Negeri 10 Makassar. Jurnal Mkmi, Maret 2015, hal. $50-58$ 